\title{
Balkanologie
}

Balkanologie Revue d'études pluridisciplinaires

Vol. XIV, $n^{\circ}$ 1-2 | 2012

Volume XIV Numéro 1-2

\section{«Graecomans » into Bulgarians : Shifting Perceptions of Greek-Bulgarian Interethnic Marriages in the Nineteenth Century}

\section{Evguenia Davidova}

\author{
(2) OpenEdition \\ Journals \\ Édition électronique \\ URL : http://journals.openedition.org/balkanologie/2342 \\ DOI : $10.4000 /$ balkanologie.2342 \\ ISSN : 1965-0582 \\ Éditeur \\ Association française d'études sur les Balkans (Afebalk)
}

Référence électronique

Evguenia Davidova, « « Graecomans » into Bulgarians : Shifting Perceptions of Greek-Bulgarian Interethnic Marriages in the Nineteenth Century », Balkanologie [En ligne], Vol. XIV, n 1-2 | 2012, mis en ligne le 25 janvier 2013, consulté le 17 décembre 2020. URL : http://journals.openedition.org/ balkanologie/2342 ; DOI : https://doi.org/10.4000/balkanologie.2342

Ce document a été généré automatiquement le 17 décembre 2020.

(c) Tous droits réservés 


\title{
«Graecomans » into Bulgarians : Shifting Perceptions of Greek- Bulgarian Interethnic Marriages in the Nineteenth Century
}

\author{
Evguenia Davidova
}

I wish our quickest split with the phanariot Greeks and Greek women !!!1 Elena, the wife of the Bulgarian merchant Nikolai Toshkov in Odessa, « spoke such a good Bulgarian despite the fact that she was born into the Russified Greek family Skarlati ».2

1 The above quotes illuminate several issues addressed in this article, which examines urban social interactions within the Orthodox millet consisting of groups with concurrent ethnic, linguistic, cultural, social, and professional identities. Such multiple affiliations existed within a cosmopolitan polylinguistic mix in which, until the 1830s, Greek language and culture was a « conduit for cultural change, intellectual and social mobility $»^{3}$. The perceptions of Greek-Bulgarian interethnic marriage coalesce the intersection of language, culture, class, gender, and nationalism, as alluded to in the epigraphs. It is the contention of this article that the transition from the multiethnic Ottoman Empire to nation-states led to emergence of intra-millet ${ }^{4}$ conflicts and intermarriages, a natural demographic process amongst mixed populations, became ideologized and entered national discourses that ascribed new meanings to family, women, and motherhood as repository of national language and identity.

2 Whereas the conflicts around the movement for an autocephalous Bulgarian Church have received ample scholarly attention, the theme of interethnic marriages as a form of socio-cultural and economic osmosis and a window into everyday life experiences remains understudied. This is, though, not a demographic research on marital patterns but a study of marriage's incorporation into the Bulgarian national discourses. Since 
family was enmeshed in a multifaceted urban fabric, it is grounded in a variety of perspectives and sources : correspondence, bishopric's records, travelogues, epistolary guides, newspapers, and memoirs. While some commercial letters illuminate the processes of urban economic power dynamics, social mobility, and various levels and types of hellenization, especially in Istanbul (Constantinople, Tsarigrad), Plovdiv (Philippoupolis, Filibe), Veliko Tŭrnovo (Tarnovi, Tyrnovo), Sliven (Selimno, Islimiye), and Edirne (Adrianople, Odrin), the memoirs and newspapers reflect the anxiety of Bulgarian national assimilation. I argue that such mixed marriages reveal pragmatic practices of auto-hellenization as expressions of eclectic urban lifestyles that flourished in the Ottoman context up to the 1830s, a process interrupted by the emergence of nation-states and the Tanzimat (1839-1876) in which the groups with fluid sense of belonging became easy targets of criticism and their social reproduction faded away. Thus, intermarriages became a crystallization of broader socio-political, economic, and cultural phenomena of disappearance of porous and mobile identities in the prenationalist Balkans and gradual hardening of national consciousness within the same communal space. These shifts were not tension-free and were integral part of the process of rearticulating of what meant to be "Orthodox", "Greek", and "Bulgarian".

The terminology we use today seems to elude the layered meanings that forms of belonging had in various contexts of the late eighteenth and nineteenth century. Prenational identity allowed rich forms of social and professional communication and collaborations. Ironically, it was the same pre-national sense of belonging that also stimulated the first national revolution in the Balkans. For instance, the Gabrovo merchant hacı Khristo Rachkov allegedly contributed financially to the Greek War of Independence, and after the death of the Patriarch in Constantinople, committed suicide in $1821^{5}$. His death raises the question of his identity : was he a "Christian", a "Bulgarian", a "Greek", an "Ottoman", or all together? The co-existence of multiple exo- and endo-appellations for various groups, expressed in a complex lexicon, corroborates the fact that terms varied from ethnic to religious to cultural to professional meanings. Romaioi (Romans), Graikoi (Greeks), and Ellines (Hellenes) were charged with different connotations but many of them were used interchangeably. The latter often referred to the ancient Greeks. The former pertained to all Eastern Orthodox Christians who were considered Romans and hence Rummillet. Foreign sources frequently used "Greeks" to designate the same category". Thus, "Greeks" and "Greek merchants" were employed to connote mostly Eastern Orthodox traders from the Ottoman Empire in both central Europe and southern Russia. Similarly, often designations such as "Greek" and "Bulgarian" reflected more divisions of labor (merchants and peasants) and social stratifications than ethnicity or language ${ }^{7}$.

4 Paschalis Kitromilides has convincingly challenged the claims of the national historiographies that the Orthodoxy was a "champion of nationalism» and contributed to the "national awakening». It did contribute, however, not to the preservation of the national but a common religious collectivity. He has argued that the creation of the modern state, a phenomenon that does not always coincide with industrialization, brought up nationalism ${ }^{8}$. Hence, the emergence of the first independent state in the Balkans changed the picture dramatically, and as Basil Gounaris aptly put it, Greek language acquired ethnic aspects and became " "Greek" to most of the Balkan peoples $"$ " and eroded the idea of shared Balkan culture. With the creation of the Greek state, the debates about "Greek" and "Greekness" intensified and forms of belonging, such as language, religion, customs, and culture began to be 
redefined in secular terms. While the Patriarchate favored an ecumenical perspective, it was the secularization of the Greek intellectuals, under the impact of the Enlightenment, who first destabilized the unity of Rum millet ${ }^{10}$. The missing link was the Byzantine past and the Greek Romanticism « reinvented Byzantium as a Hellenic Empire " and thus created a coherent national narrative. However, the dichotomy between Hellenism and Romeicism did not fade away but continued to resurface, disguised in various contexts interpreting the Greek past ${ }^{11}$.

5 From a Bulgarian perspective, during the Middle Ages the appellations Romaioi and Greeks were employed to connote Byzantines and Byzantine culture, and to a certain extent they symbolized an educated person. By the eighteenth century the use of "Hellene" and "Hellenic" was in a sense of pagans and non-Christians. As the century unfolded, the term "Greek" became more nuanced ${ }^{12}$. It was the appearance of Istoria Slavenobolgarskaia (1872) by Father Paisiǐ of Khilendar that charged both the Byzantines and contemporary Greeks with negative connotations. It is usually considered that the Istoria began a process of ethnicization and emancipation of the Bulgarians from the Christians, a departure from the equation of Bulgarians with Greeks by contrasting poor and hard-working Bulgarian farmers and ordinary artisans to Greek merchants who were depicted as arrogant, cunning, and deceitful. With reference to this study, the Paisiin's Istoria reinforced the image of the medieval Greek princess as the "Perfidious Beauty"13, which was echoed in the first epigraph. And yet the eighteenth and early nineteenth-century Bulgarian texts manifested an ambiguity in employing Greek stereotypes. Educators and writers (Neophyte Rilski, Rajno Popovich, and Khristaki Pavlovich) supported studying Greek language. Greek-educated Bulgarians, such as Neophyte Bozveli, Ivan Seliminski, and Vasil Aprilov, some of whom participated in Philiki Etaireia and the Greek War of Independence, embodied the transformation from admirers of Hellenic culture into fervent detractors of Greek clergy; notably, by denouncing its intentional assimilating policy towards the Bulgarians ${ }^{14}$. Rhetorical devices of stigmatizing acculturation into the Greek education and lifestyles, as "graecomania", became a protective mechanism for national affirmation. The latter was clearly articulated in the early 1840 s by Vasil Aprilov. In the 1860s and 1870s, Spiridon Palauzov and Marin Drinov, the first professional historians, endorsed further refutation of the Byzantine past. Influential scholars as Konstantin Jireček repeated such opinions and promoted the widespread thesis of the double yoke: political by the Turks and spiritual by the Greeks.

6 Miroslav Hroch has emphasized the role of intelligentsia in the formulation of national goals, particularly their activities in the "phase of mobilization" ${ }^{15}$. As noted earlier, the secular Greek intellectuals paved the way to such development. Along these lines, Bulgarians educated abroad began to raise questions about secular education and liturgical service in the Slav language. This new attitude has to be seen in a broader Slavic context, namely the attempt of Slavs from the Habsburg, Russian, and Ottoman Empires to unite and the impact of Jacob Fallmerayer's denial of Greek claims being descendants of the ancient Hellenes (1830) ${ }^{16}$. Other factors also shaped the exacerbation of those intra-communal relations - the announcement of Greek autocephalous church (1833), and the articulation of the Megali idea(1844). The ushering in of the financial reforms of the Tanzimat in 1839 opened the door for competing representational positions on a local administrative level and added to the urban and rural tensions ${ }^{17}$. These conflicts were particularly prominent in mixed urban centers where Greek- 
speaking elites had dominant role in economic and representative positions of the Christian populations, such as Tŭrnovo, Sliven, and Plovdiv ${ }^{18}$.

1.

\section{Plovdiv/Philippoupolis : A Case Study for Larger Social and Political Transformations}

7 Since the mid-eighteenth century, the Bulgarian rural migration to towns increased substantially. Most newcomers, excluded from access to urban resources, adopted different social strategies of acculturation: occupation, marriage, god parentage, residence, and any combination of all. Interethnic marriages became a form of cultural adaptation and socio-economic adjustment and an expression of what can be called a pragmatic auto-hellenization. This process of assimilation into a Greek milieu meant not only adoption of an urban lifestyle and mentality but also participation in the father-in-law's business, entering into a highly developed local, interregional and international network without migrating far away from one's birth place ${ }^{19}$. Plovdiv was a typical example of a cosmopolitan Ottoman city that illuminates the complexity of these ethno-religious-linguistic-cultural and economic interactions. The arrival of apprentices there, especially among the abaciguild, often led to marriages of rural males to the daughters or relatives of their masters, or they established god parentage alliances through kumstvo (koumparia, best man or godfather) ${ }^{20}$. A recent study of generations of immigrants to Philippoupolis has argued that these demographic changes were not just short-term migrations from the neighboring countryside during the kurcals' time (1790s-1820s), as usually interpreted, but were quite prominent until the mid-nineteenth century. Andreas Lyberatos has also cautioned against ascribing national categories retrospectively ${ }^{21}$. That does not mean that ethnic distinctions did not exist, but they were more along religious, urban/rural, class, and non-national lines ${ }^{22}$.

8 Because of its mixed character, Plovdiv/Philippoupolis also became an arena of fervent nationalist conflicts, both at the level of discourses about civilization and barbarity and physical fights in the churches, especially towards the 1850s. Its eighteenth-century history is illustrative of a ruling stratum of a few families that constituted a "quasiaristocratic lay elite" engaged in long-distance trade, enjoying protection by the Ottoman administration and the Orthodox Church, and holding titles of the Byzantine nomenclatures of ranks $^{23}$. Their social reproduction, including mixed marriages between the young ladies (kokkona) and Christian entrepreneurial migrants from the countryside, was maintained through Greek language and culture. Thus, the Greek teacher Georgios Tsoukalas in 1851 minimized the Bulgarian presence in the city by stating that since Antiquity most dwellers, according to their "religion, language, and mores", had always been Greeks and the few Bulgarians there were "hellenized" $($ $\rho \alpha \iota \kappa l \zeta o v \sigma l)$. His argument was based on the superiority of Greek culture, and most specifically, the preeminence of Greek literacy and education ${ }^{24}$. Hence, one could find two brothers born by the same Greek mother and two different fathers and both are Greeks : one by birth because both his parents were Greek ; the other, in spite of having a Bulgarian father, was also Greek due to his upbringing, language, diet, behavior, etc. 25 .

9 By contrast, Konstantin Moravenov, a Bulgarian merchant, educator, and activist wrote a demographic memoir ${ }^{26}$ in the late 1860 s. That decade witnessed a new phase of 
aggravation of the conflicts between the two ethnic parties in Plovdiv ${ }^{27}$. The author himself personifies the transformation of auto-hellenism based on culture and class into ethno-nationalism based on language and ideology. He was born around 1810-1812 and knew only Greek until the age of 45 when he began learning Bulgarian ${ }^{28}$. Like Tsoukalas, his nationalist ethos colors the entire text. It seems that Moravenov's manuscript was written as a rejoinder to Tsoukalas' book. While the latter tried to establish the Greek prevalence by using archeological as well as historical evidence, Moravenov employed a different approach ; namely, a form of "oral history" by paying attention to people and their property relations in order to prove that the "pure" Greeks were actually "pure" Bulgarians who recently have adopted Greek language and lifestyle. In this respect, it is quite possible that both Tsoukalas and Moravenov were familiar with Jacob Fallmerayer's arguments and addressed the issue of continuity between the ancient and contemporary Greeks from two opposing perspectives.

Moravenov described Plovdiv as consisting of Turks, Bulgarians, Gudilas (Hellelnized Bulgarians from Plovdiv), Armenians, Jews, Cincars, Arnauts (Albanians), Langeris (Hellelnized Bulgarians from Plovdiv's surroundings), ethnic Greeks who came from Greece or other parts of the Ottoman Empire, and Gypsies ${ }^{29}$. The hellenized Bulgarians were considered renegades, pejoratively called "Graecomans". Raymond Detrez has suggested that when the Gudilas and Langeris claimed to be Greek it was more in the sense of "Romei than Ellines, in a cultural rather than an ethnic sense" ${ }^{30}$. Moravenov, though, tried to ethnicize their identity by satirizing their claims of belonging to Greek culture as unauthentic. Table 1 and Table 2 below are based on data extrapolated from the Moravenov's text. Table 1 depicts the ethnic picture of the central neighborhoods of Plovdiv; it derives from the calculations done by two researchers of Plovdiv/ Philippoupolis. The data is both similar and dissimilar, especially with respect to numbers of the Bulgarians and Gudilas, due to different methodological criteria. Lyberatos has employed a more nuanced category: owners/tenants; he has also identified more ethnically diverse groups. According to both calculations, the Bulgarians constituted around one third of the population (in Genchev's case even a higher percentage) ; the Hellenized Bulgarians varied between 49-51\% (this percentage includes Gudilas, Langeris, Bulgarian parents with children Gudilas, "either Gudilas or Bulgarians", and Greeks/Bulgarians). Since the data is referring to the city's central parts, such demographic picture is not surprising because the affluent dwellers and the Grecophone urban elite were concentrated there, as Sliven's cityscape corroborated this trend ${ }^{31}$. Of interest is the group of "Bulgarian parents with children Gudilas", which shows the perception of loosing ethnic identity within the next generation even without mixed marriages and illustrates the thesis of pragmatic auto-hellenization. Moreover, Lyberatos has done additional calculations tracing back two generations and they reveal a steady increase of both categories Gudilas and Langeris over most of the nineteenth century ${ }^{32}$.

Table 1. Households; Owners/renters in the central part of Plovdiv

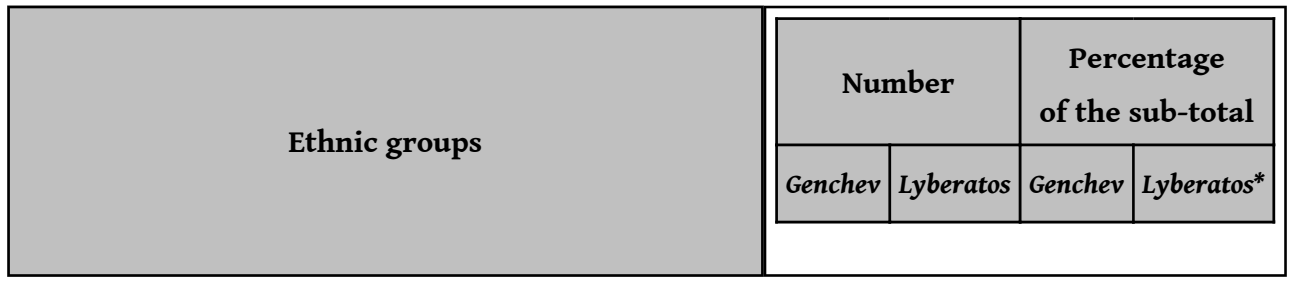




\begin{tabular}{|c|c|c|c|c|}
\hline Bulgarians & 141 & 118 & 39.4 & $\begin{array}{r}33.7 \\
{[31.9]}\end{array}$ \\
\hline $\begin{array}{l}\text { Gudilas } \\
\text { (Hellenized Bulgarians from Plovdiv) }\end{array}$ & 94 & 141 & 26.3 & 38.1 \\
\hline $\begin{array}{l}\text { Langeris (Helelnized Bulgarians from Plovdiv's } \\
\text { surroundings) }\end{array}$ & 36 & 39 & 10.1 & 10.5 \\
\hline $\begin{array}{l}\text { Cincars } \\
\text { (Vlachs) }\end{array}$ & 12 & 14 & 3.3 & 3.8 \\
\hline $\begin{array}{l}\text { Arnauts } \\
\text { (Albanians) }\end{array}$ & 7 & 6 & 2 & $1.4[1.6]$ \\
\hline $\begin{array}{l}\text { Pomaks } \\
\text { (Bulgarian-speaking Muslims) }\end{array}$ & 9 & 5 & 2.5 & 1.4 \\
\hline $\begin{array}{l}\text { Karamanlis } \\
\text { (Turkish-speaking Orthodoxes) }\end{array}$ & & 2 & & 0.5 \\
\hline $\begin{array}{l}\text { Greeks from Greece or other parts of the Ottoman } \\
\text { Empire }\end{array}$ & 14 & 17 & 3.9 & 4.6 \\
\hline Bulgarian parents with children Gudilas & 41 & & 11.4 & \\
\hline $\begin{array}{l}\text { Either Bulgarians } \\
\text { or Gudilas }\end{array}$ & 4 & & 1.1 & \\
\hline Greeks/Bulgarians & & 8 & & 2.2 \\
\hline Armenians & & 20 & & 5.4 \\
\hline Sub-total & 358 & 370 & 100 & 100 \\
\hline Unidentified/Incomplete information & 63 & 73 & & \\
\hline Total & 421 & 443 & & \\
\hline
\end{tabular}

The data is compiled by N. Genchev and A. Lyberatos.

* In brackets : my recalculation

Source: Genchev (NikolaI), op. cit, p. 67; Lyberatos (Andreas), « To "Mnēmeio" » (art.cit.), p. 361.

In Table 2, I compiled the information (with all its bias) about mixed marriages and broke them down into various combinations. First, the Bulgarians were the predominant population and their percentage of endogenous marriage was the highest $(42,4 \%)$. Yet their inclination towards finding a bridal partner outside the group was even higher $(57,6 \%)$ : they married mainly Gudilas, Greeks, and Cincars. Second, both Gudilas and Langeris, locally born populations, had very high exo-marriage numbers (including foreigners) and appear to have a lower self-reproduction percentage $(16,7 \%$ 
and $25 \%$, respectively). They also showed somewhat of a fluid identity; Moravenov wrote that they identified themselves contextually: "[a Gudila] either manifests himself a Gudila or a Bulgarian, [it] depends on what fits him best $"^{33}$. Third, it is no surprise that the newcomers to the city intermarried with local people as in the case of ethnic Greeks, Cincars, Arnauts, and Arabs. Bernard Lory has noted that marriage and profession were the main means of social integration. Both Lory and Lyberatos have attracted attention to the role of women in property circulation and transmission, which enabled their husbands' economic incorporation into the urban tapestry as well ${ }^{34}$. Research on dowry contracts in Athens has also demonstrated that demographic, economic and political circumstances, such as an influx of male immigrants to Athens in the 1830s from other regions, increased the value of the urban property, owned by female owners ${ }^{35}$.

Table 2. Interethnic marriages in Plovdiv

\begin{tabular}{|c|c|c|c|c|c|c|c|c|}
\hline Ethnic Group & $\begin{array}{l}\text { Bulgarians } \\
\text { (B) }\end{array}$ & $\begin{array}{c}\text { Gudilas } \\
\text { (G) }\end{array}$ & $\begin{array}{l}\text { Langeris } \\
\text { (L) }\end{array}$ & $\begin{array}{c}\text { Cincars } \\
\text { (c) }\end{array}$ & $\begin{array}{c}\text { Ethnic } \\
\text { Greeks } \\
\text { (GR) }\end{array}$ & $\begin{array}{c}\text { Arnauts/ } \\
\text { Albanians } \\
\text { (A) }\end{array}$ & $\begin{array}{c}\text { Arabs } \\
\text { (AR) }\end{array}$ & Other \\
\hline $\begin{array}{l}\text { Endogamous } \\
\text { marriages }\end{array}$ & $B-B 56$ & G-G 15 & $L-L 7$ & $C-C 2$ & & A-A 1 & & \\
\hline $\begin{array}{l}\text { Bulgarian } \\
\text { intermarriages }\end{array}$ & & $B-G 40$ & $B-L 6$ & $B-C 12$ & B-GR 15 & B-A 2 & & B-Turk 1 \\
\hline $\begin{array}{l}\text { Gudilas } \\
\text { intermarriages }\end{array}$ & G-B 40 & & G-L 5 & $G-C 7$ & G-GR 14 & G-A 1 & $G-A R 1$ & $\begin{array}{c}\text { G-Foreign } \\
7\end{array}$ \\
\hline $\begin{array}{l}\text { Langeris } \\
\text { intermarriages }\end{array}$ & $L-B 6$ & $L-G 5$ & & $L-C 1$ & $L-G R 6$ & $A-L 2$ & & $\begin{array}{c}\text { L-Foreign } \\
1\end{array}$ \\
\hline $\begin{array}{l}\text { Cincars } \\
\text { intermarriages }\end{array}$ & $C-B 12$ & $C-G 7$ & $C-L 1$ & & $C-G R 1$ & & & \\
\hline $\begin{array}{l}\text { Greek } \\
\text { intermarriages }\end{array}$ & GR-B 15 & GR-G 14 & GR-L 6 & $G-C R 1$ & & & $\begin{array}{c}\text { GR-AR } \\
2\end{array}$ & $\begin{array}{c}\text { GR- } \\
\text { Armenian } \\
1\end{array}$ \\
\hline $\begin{array}{l}\text { Arnaut } \\
\text { intermarriages }\end{array}$ & $A-B 2$ & $A-G 1$ & $A-L 2$ & & & $\begin{array}{l}\text { A-Catholic } \\
\text { (Paulician) } 1\end{array}$ & & \\
\hline $\begin{array}{l}\text { Arab } \\
\text { intermarriages }\end{array}$ & $A R-B 1$ & $A R-G 1$ & & & AR-GR 2 & & & \\
\hline Total number & 132 & 83 & 27 & 23 & 38 & 7 & 3 & 10 \\
\hline $\begin{array}{l}\text { Endogenous } \\
\text { marriages } \\
\text { Percentage }\end{array}$ & $42.4 \%$ & $18 \%$ & $26 \%$ & $8.7 \%$ & & $14.3 \%$ & & \\
\hline
\end{tabular}




\begin{tabular}{|l|c|c|c|c|c|c|c|c|}
\hline $\begin{array}{l}\text { Exogenous } \\
\text { marriages } \\
\text { Percentage }\end{array}$ & $57.6 \%$ & $82 \%$ & $74 \%$ & $91.3 \%$ & $100 \%$ & $85.7 \%$ & $100 \%$ & $100 \%$ \\
\hline
\end{tabular}

Source: Moravenov (Konstantin), Pametnik za Plovdivskoto khristiansko naselenie v grada i za obshtite zavedenia po proiznosno predanie, ed.Victoria Tileva and Zdravka Boneva, Plovdiv : izdatelstvo "Khristo G. Danov", 1984.

1.

\section{From auto-hellenization to de-hellenization}

One of the earliest calls for auto-hellenization was expressed by Daniel of Moschopolis $(1762 / 1802)$ in his Eisagogiki Didaskalia (Introductory Instruction) : « Acquire the tongue and speech of the Greeks, Greatly benefit in your professions,/ And in all your commercial undertakings $»^{36}$. The invitation has a clear economic and social subtext; its eager reception (in the sense of Christians, Romaioi) can be traced not only through education and commerce, but also through mixed marriages in various cities in the central Balkans.

The theme of hellenization has been largely examined elsewhere ${ }^{37}$. The term contains multiple meanings and groups: first, Greek-speaking non-ethnic Greek intellectuals, mostly clergy, teachers, scholars, or some combination of them who assimilated into Greek culture; Iosipos Moisiodax being a sterling example. Second, the previously mentioned "Greek merchants" who also constituted a rich inter-Balkan group that consisted of Greeks, Cincars, Serbians, Bulgarians, Orthodox Albanians, Romanians, and Vlachs. Third, arguably the biggest element of all three, were the urban elites in the Ottoman cities. That class of people became grecophone, changed their names, married into Greek-speaking families, sent their children to Greek schools, and supported Greek culture on a local level ${ }^{38}$. All these degrees of urban auto-hellenization varied according to time and social belonging, but the adoption of the Greek language as a marker of cultural, religious, and professional sense of belonging was an important element. For instance, Mikhail Madzharov, a Bulgarian politician, described in his memoirs that a young village newcomer to Plovdiv would learn from his master (who was himself a "Greek or hellenized Bulgarian") the Plovdiv Greek language ${ }^{39}$. Another reference to substandard Greek comes from Moravenov, who mentioned that a certain Bulgarian in Plovdiv «learned to jabber gudilski [Gudilain language] and therefore became a Gudila $»^{40}$. Both examples refer to language use with localized semantics as well as taxonomy of languages of which Gudilain language is not considered authentic Greek, but also the assumption that language itself can bring change to ethnic identity. Raymond Detrez has argued that Gudilian was both "language process," shaped under protracted Bulgarian and Greek influences, and a "language outcome" as the Gudilas chose to learn this not "pure" Greek language because it expressed best the Gudilian identity, which overlapped with the stratum of petite bourgeoisie in Plovdiv ${ }^{41}$.

The kondika (register) of the Tŭrnovo municipality (1778-1819) is also quite illustrative of the process of absorption of Greek language and culture. It was written in Greek, and yet the language was a blend of vernacular and written language with a rich mixture of Bulgarian and Turkish words. Many of the names have a Greek ending, such as hacl Nikolchos Penchos ${ }^{42}$. Similarly, in the Greek codex of the Philippoupolis bishopric, the female names are mostly Greek, such as Anasthasia, Zoē, Melahro, Smaragda ${ }^{43}$. The 
subscribers' networks for Greek books and newspapers, even from towns (such as Gabrovo) where the Greek presence was rather thin, are instructive of the dissemination of Greek language and culture amongst the educated Bulgarians. Thus, around 1801 the previously mentioned Khristo Rachkov became Khristo Rachkov Grek $(G r e e k)^{44}$. This change suggests an expansion of his transactions with the "Greek merchants" in Wallachia, Russia, and Central Europe. This auto-hellenization did not seem to be exceptional nor did the perception of interethnic marriages appear to be problematic until the 1830s. For example, the above-mentioned Philippoupolis bishopric register mentions ethnicity in inheritance and divorce documents only in few cases of different confession.

There were multiple other ways that illustrate this cultural, social, and professional auto-hellenization. For instance, often merchants compiled notebooks for daily use. A manuscript entitled "Greek/Bulgarian Dictionary/Conversation Guide" 45 introduced urban manners, values, and forms of sociability, such as invitations for home visits, going for a walk, shopping, and going to a play. Epistolary guides offer another indirect glimpse into urban social exchanges. One manuscript from around 1809 contains a hypothetical sample of a letter from a son to his father (kyr Ilia) and his mother by their son Konstantin ${ }^{46}$. Up to 1830s, the use of kyr (mister) and kyria (madam, lady) as a form of respect was very common. While this guide displays a mixture of Christian names and Greek addresses of respect, another manuscript, compiled between the 1830 s and 1840s, demonstrates a "Slavianization" of the names and addresses between husband and wife and uses the Ottoman names of the cities. Thus, the husband becomes "gospodin [mister] Ianko Voulkovich" from Filibe and "gospodin Stefan Petrovich" from Selânik, and the wife is "sopruga [wife] gospozha [madam] Maria Ioannovich" from Filibe ${ }^{47}$. The last example speaks to the beginning of an early transition from auto-hellenization to de-hellenization, a trend that received prominence in the second half of the century. Lucian Boia discusses a similar process in the Danubian Principalities where French, immediately after 1830, replaced Greek as language of culture and played a significant role in shaping Romanian identity. This cultural shift was accompanied by a transition from Oriental attire to Parisian fashion and education ${ }^{48}$.

Many scholars have mentioned that Greek became the lingua franca in the nineteenthcentury Balkans ${ }^{49}$. Georges Dertilis has considered Greek used by the Balkan merchants a kind of "interbalcanic" language ${ }^{50}$. Yet it seems that there were a few more layers than suggest the previously mentioned examples. A mixed language, what I would call a Balkan commercial koinē, based on Greek but heavily interspersed with Turkish/Arab/ Persian, and Bulgarian/Slav words, is pervasive in the commercial archival sources, especially in the first half of the nineteenth century. For instance, a contract sample in an epistolary manual was called "omologia [Greek] za [Bulgarian] ourtachuvanu [Turkish, corrupted version for ortakluk]" ${ }^{51}$. Other cases derive from business partnership contracts, written in Bulgarian (with Greek letters), Greek, and Bulgarian, all sprinkled with Turkish expressions, by the same merchant ${ }^{52}$.

These multilingual practices were commented upon by many contemporaries. Consider the example of the Russian female traveler Maria Karlova, who visited Macedonia in 1868. She was impressed by the Bulgarians in Negoš who knew both Greek and Bulgarian but preferred Greek "as a more cultured and fashionable language » in society and Bulgarian at home and in the surrounding villages ${ }^{53}$. As well, the Bulgarian 
teacher Rada Kirkovich described Plovdiv around the mid-1860s as still very hellenized with regards to language :

Bulgarian language was appreciated only in Marasha, Karshiaka [neighborhoods] and among the maids, but in the city there was rarely a family where they talk in Bulgarian. Only men were speaking in Bulgarian among themselves, and almost all their wives were speaking in Greek. There was no exception even in the families of the most prominent Bulgarian patriots. ${ }^{54}$

The quote reveals not just gender but also class differences that might explain the fervent criticism against grecophone wives while sparing the reproach of their bilingual husbands. Desislava Lilova has also offered examples of Bulgarian language's marginalization and its stigmatization as "rural" (selski) $)^{55}$. The existence of a public language sphere $v s$ an informal one was similarly noted by Victor Grigorovich, another Russian traveler and Slavist scholar, who also visited Macedonia in the 1840s to collect linguistic expressions. He stated that it was difficult to study Bulgarian because the population spoke either Turkish or Greek in public : «It is only in their homes, with help of the female, who is well known for being shy, that I was able to discern the [Bulgarian] lexical wealth ». Grigorovich pointed out to the importance of mother's tongue use at home, a crucial element in the subsequent national debates as Kirkovich's quote demonstrates. He continued that especially in Macedonia, the Bulgarians often mix the three languages. Moreover, in schools the children of merchants and artisans studied Greek, which often was taught in a rhetorical manner, mixing everyday expressions with ancient phrases ${ }^{56}$. This blending mirrored the contemporary language discourses in Greece. Although they were centered on the language question, as Michael Herzfeld has suggested the debates were more about "Hellenist" and "Romeicist" ideologies; the latter being nurtured by the church's disapproval of "Hellenism", the continuation of Roman law in Byzantium, and the millet system ${ }^{57}$. Accordingly, modern Greek language was "highly ideologized" and had to accommodate the "expression of all aspects of the political and cultural life of a modern European nation that saw itself as a heir to a unique and glorious ancient tradition $»^{58}$. In the long run these debates elevated the ideology of linguistic nationalism and added to the erosion of the idea of common Balkan future, including at family level.

In the 1850s and 1860s, with the intensification of the Bulgarian movement for an autocephalous church, the appellations Romaioi, Byzantines, Hellenes, and Greek blended and were filled with negative associations through reinterpretation of events from Antiquity and the Middle Ages. For example, publicists from the 1860s, and especially Petko Slaverkov, contributed to the dissemination of the legend that the Tŭrnovo Patriarchate's library was put on fire deliberately by the Tŭrnovo's bishop Ilariōn who was a Greek ${ }^{59}$. In the 1870 s and the 1880 s, especially after the establishment of the Bulgarian Exarchate in 1870, the relations aggravated : "The Greek national and historical imagination was accordingly recasted, and embarked on a process that would transform the Bulgarians from harmless peasants and good Christians into bloodthirsty barbarians $"^{60}$. Moreover, many Greek contemporaries perceived the rupture of 1872 mostly in terms of foreign intervention and not as development of phases of hostility ${ }^{61}$. The victims of such hardening of national sentiments became a variety of inbetween groups that stemmed from the multiethnic, multi-religious, and multilinguistic coexistence in the Ottoman cities. The violence that erupted in Macedonia can be seen as an apex of divisive processes that were unleashed in the 1830s in intra- 
communal, Ottoman, and international contexts, which were translated at the level of private sphere and impacted the perceptions of marriage and family as well.

1.

\section{Practices and Discourses about Mixed Marriages}

20 It is known that many marriages were arranged, especially for women who were born into well-off families and brought substantial dowry ; the latter expressed their family's financial and social standing. Most Greek diaspora marriages, especially in central and western Europe, were "heavily endogamous" and consequently based on a model of contracted marriages ${ }^{62}$. Early female marriages and even earlier betrothals were quite common. A case in point was Cincars' model of late male and early female marital age, called by Dušan Popović a "Greek bridegroom". For example, Andrija Dada, a Belgrade merchant, was married at the age of 42 to a 16 -year old girl ${ }^{63}$. Western female travelers discussed such type of arranged marriage in terms of patriarchy and backwardness, through Orientalist lenses, though. Mary Adelaide Walker, who traveled in the 1860s in Macedonia and Albania, was critical of Greek treatment of pre-marital girls. She described that "amongst old-fashioned Greek families" girls were kept in seclusion they stopped attending school after the age of twelve or fourteen, they didn't go abroad, and no more than twice a year would go to church. Thus, this «complete imprisonment " made them look forward to an early marriage as the "only hope of emancipation $»^{64}$. Despoina Vlamē has also confirmed that the late male marriage was typical for Greek merchants, particularly in Italy, and placed this phenomenon into the context of professional ambitions for success ${ }^{65}$. And this makes sense, having in mind that demographic studies on the nineteenth-century Balkans have demonstrated that men outnumbered women at a sex ratio between 109,6-103,5; furthermore, this was a common urban phenomenon ${ }^{66}$. Consequently, in such a competitive environment affluent men would get better chances to marry, but they would need more years to accumulate their wealth. On the other hand, the data in Table 2, compiled from Moravenov's text, provides the opposite example: all of the 38 ethnic Greek immigrants to Plovdiv/Phippoupolis married to non-Greek women. This disparity might be explained by the fact that there was a substantial grecophone population prone to intermarry while in places like Livorno and Vienna the diaspora merchants were surrounded by non-Orthodox majority.

In pre-industrial societies the institution of marriage maintained social cohesion, and the Orthodox Church and local communities carefully monitored any departures from established rules that posed threats to stability. In the nineteenth century, various new factors influenced family practices and perception of marriage. First, the Ottoman reforms attempted to curtail the autonomy of the Orthodox millet through handling cases of marriage, wills, and divorce to civil courts, and some penal cases to criminal courts. Nevertheless, the Ecumenical Patriarchate did not eagerly accept these inroads and resisted this aspect of the Ottoman institutional modernization ${ }^{67}$. Second, under the impact of Romanticism and with the advancement of nationalism, family and women came to be seen as major keepers of national language and repository of traditional national values. Third, the incorporation of the Balkans and the Ottoman Empire into the world capitalist economy brought about economic and sociodemographic changes that affected family patterns as well. 
If one looks at some individual stories, a more nuanced picture emerges of a model that hat can be called a local middle class marriage. A certain Christian Konstantou, a widow of an affluent Armenian Agop Dzeveleki, inherited property valued at 39,200 kuruş, which was divided in shares between her and her father-in-law at the kadı court in $1833^{68}$. The recourse to the Muslim court seems to be prompted by their belonging to two different communities: Rumand Armenian millet. Another example is a divorce document between a Swedish doctor Birda and a certain Anna. Again, the procedure involved both the kadi first and a confirmation by the bishop in $1838^{69}$. Anton Utenberg, a Samokov doctor from Polish origin, remarried to Euthimia Konstantin Mētkoglou in 1849. The marriage ritual was performed in the monastery St. Anargisi and the certificate was written in Greek ${ }^{70}$. Tables 1 and 2, discussed earlier, as well as the individual cases, suggest that Greek-speaking females were more prone to marry husbands from other ethnicities; a fact that confirms that intermarriage was an important factor for social integration of immigrants as well as an institution for transmission of property in urban settings. Such was the case of the marriage between Georgi Sŭrmabozhov, an immigrant terzi (tailor), and Kleiō Sarmampozova who inherited from her father a house in Ohrid. ${ }^{71}$ Nonetheless, these economic and social aspects of intermarriage seem to be missing from the national debates, which focused on the risks of loosing one's sense of national belonging.

Interethnic marriages were a natural demographic phenomenon; however, they attracted attention only when they were perceived as dangers to community's cohesiveness. There were various types of critical examination concerning the threats that mixed marriages posed. Often their arguments overlapped. The first approach can be labeled as a patriarchal and traditional Orthodox critique. This disapproval emerged with reference to diaspora merchants. For example, Stamatis Petrou, Adamatios Korais' servant, who accompanied him in Amsterdam in 1771, expressed earlier concerns about inter-confessional marriages. His letters were written from a traditionalist, patriarchal, and conservative standpoint. He was scandalized that his master fell in love with a Calvinist woman and even intended to marry her ${ }^{72}$. Along the same vein, an anonymous author of a polemic piece, The Greek Monarchy or a Word about Freedom, published in 1806, discussed the theme of young Greeks in Western Europe marrying non-Greek wives. The author wrote : «I say about those who, to our misfortune, are not few, who to estrange themselves for ever from Greece and to forget even its name, have decided with extreme foolishness to take a foreign woman in a foreign land for a wife $»^{73}$. In the first instance faith was under threat; in the second example, written about 30 years later, the xenophobic element seems to transcend religion and to warn about loss of cultural identity.

As stated in the first epigraph, a Bulgarian merchant echoed this xenophobic attitude some 40 years later. He wrote from Tsarigrad to his boss in Tŭrnovo that he wishes " our quickest split with the phanariot Greeks and Greek women !!! »" His criticism targeted coreligionists who indulge in luxurious lifestyles; it has a class element. Unlike the previous cases, around mid-nineteenth century, members of the same millet embodied the Other. It is not anymore religion and cultural difference that posed threats but ethnicity and the letter implies the risk of Bulgarian denationalization that a city woman brings with her Greek language and refined manners. This call is resonant with the medieval characterization of the Byzantine princesses mentioned earlier. The issue is broader, though, and reflects discourses on gender, education, and 
motherhood. For example, in Greece there existed two opposing but nonetheless negative stereotypes : the illiterate and backward woman and the graduate from a girls' school who was « conceited, frivolous, vain, full of useless knowledge, forever parroting foreign modes, of suspect sexual morality, and, of course, highly unreliable as a mother $»^{75}$. In the cited letter, the second stereotype is not only implied but also enriched with nationalist fervor.

Bulgarian anxieties were manifested particularly since the mid-1850s when ecclesiastical struggles exploded in many cities with mixed population where Greekspeaking elites dominated cultural, administrative, and economic life. Both educated male and female Bulgarians expressed negativist perceptions of Greek women and mixed marriages. Those critical dispositions had much deeper causes, rooted in the late nineteenth-century political, socio-economic, and ideological conflicts but were vested in national and gender garb. The discourse obtained a visible national aspect and the "Perfidious Beauty" was seen not only as immoral but also as sort of a "fifth column", associated with the existence of the independent nation-state Greece, that could snatch healthy parts from the masculine national body:

A substantial part of [Bulgarian] youth remained bachelors because the female element was scarce amongst the Bulgarian colony [in Tsarigrad] and they believed that if they marry Greek women, they would loose their nationality or at least the nationality of their children... The examples of the older Bulgarians who were married to Greek women were not very encouraging with regards to keeping their Bulgarian nationality. ${ }^{76}$

Unlike previously mentioned local middle class marriages, the Ottoman capital, was especially threatening as it offered a phanariot elite marriage, or an access to leading Greek families. A case in point was Gavril Krŭstevich/Gavriēl Krestovits, an Ottoman bureaucrat and supporter of the Bulgarian autonomous church, who married to Euphrosina Sophianou and thus became connected to the powerful families Karatheodōrēs and Mousouros. Another example provides Stefan Bogoridi/Stephanos Vogoridēs who married to Ralou from the influential phanariot family Skylitzi. A third instance derives from Alexandŭr Ekzarkh's marriage whose wife Sophia was a relative of the Odessa's prominent Maraslis family ${ }^{77}$.

In Dobrudja, though, the threat came from Rumanian and Gagauz women : « Men were married to Gagauz women who not only hated Bulgarian language but also succeeded in assimilating [pretopiat] their husbands... The peaceful Bulgarian, being ignorant, preferred to sacrifice his father's tongue [my italics] and even to forget it in order to keep peace at home ${ }^{78}$. Note the patriarchal component - unlike Grigorovich -- who referred to the mother language, the quote above expressed language as masculine attribute of the nation, albeit manipulated by foreign women. This angst, which implied an emaciation of Bulgarian national masculinity, seems to be perpetuated by the Bulgarian journalist and writer Slaveikov, who maintained a social column in his newspaper "Gaĭda". His sarcasm was especially directed at Bulgarians who married Greek women. One of the common targets was the above-mentioned Gavril Krŭstevich. The contempt against him was not spared even from his mother's obituary -- Ralou Krŭstides (Rada Baeva), which was published in Greek (1875). It said that her son: "Gavril effendi hellenized not only his own name, but also the name of his mother at her old age $»^{79}$. Another Bulgarian writer and journalist, Liuben Karavelov, also discussed the denationalizing role of Greek and Gudila women in Plovdiv who were changing the identity of their husbands and children ${ }^{80}$. However, those personal attacks 
obscure substantial ideological divisions among the Bulgarians about the paths to national independence; namely, moderates like Krŭstevich vs radicals like Slaveǐkov and Karavelov ${ }^{81}$.

An imprint of moral accusation permeated also the first Bulgarian comedy, Lovchanskiat vladika ili bela na lovchanskiĭt sakhatchia, written in 1857 by Teodosiǐ Ikonomov, a teacher and publicist ${ }^{82}$. The plot revolves around the adultery of a Greek wife with a Greek bishop and highlights low morality as an ethnic attribute. It captures the Bulgarian fears of Greek dominance in both the public (ecclesiastic) and informal (family) life. The same negativism and fear of hellenization directed at wives comes from the previously cited Rada Kirkovich, a teacher in the Plovdiv girls' school. She was lamenting the fate of a female friend of hers who had to live in Odrin with her Greek sisters-in-law, and it is "known what was the attitude of the Greeks towards the Bulgarians ${ }^{83}$. The comment has a clear national distinction and reinforces the idea of intra-communal tensions where mixed marriage came to be seen as form of national assimilation and loss of one's Bulgarianness ${ }^{84}$.

Contrary to nationalist anxieties, there were examples of exogamous marriages where nationality was not lost but enriched. For example, Rallē hacı P. Mavridi, a merchant from Shumen, was socialized in a Greek milieu. He married to a Greek-speaking wife and yet his son Panagiotis was baptized in the Bulgarian church "St. Stefan" 85 . That double belonging (he also had a Greek passport) did not seem to restrain him from supporting Bulgarian newspapers, the establishment of the Bulgarian city council in Varna, and a Bulgarian school there. Additional instance offers the Bulgarian merchant Nikolar Toshkov in Odessa who was married to Elena who "spoke such a good Bulgarian despite the fact that she was born into the Russified Greek family Skarlati ${ }^{86}$. And yet Toshkov established scholarships for Bulgarian female students in Russia ${ }^{87}$. A third case comes from the previously mentioned Surmabozhov family: the mother wrote only in Greek but all children maintained a mixed correspondence in Greek with her and in Bulgarian among themselves ${ }^{88}$.

Additional expression of concurrent belonging to both Greek and Bulgarian communities is disclosed in multiple donations in wills. Those patterns of behavior continued until at least the mid-1850s. For example, the previously mentioned Stefan Bogoridi, a high Ottoman official, donated his land in Phanar for the building of a Bulgarian church there in $1849^{89}$. The fact that those people contributed to various Christian charitable endeavors allowed them to have somewhat of a transferable identity, expressed even in the choices of names that they used in various contexts, such as business correspondence, administrative contacts, and charity. Thus, Stefan Bogoridi (name at birth, Storko Stoı̌kov) was also known as Stephanos Vogorides and Istefanaki Bey. However, the respective national historiographies ignored those multiversioned names and purged their protean identities by adopting only one rendering of the names. In the same manner, the intermarriages became a "nuisance" in the process of constructing single national identities ${ }^{90}$.

1.

\section{Conclusion}

31 So far, I have tried to argue that a natural demographic process among ethnically mixed populations, which existed for centuries, became ethnicized, politicized, and ideologized since the 1830s. The examples of early tolerance and subsequent rage 
against mixed marriages suggest that the new "imagined communities" began to delimit new ethnic boundaries within the same communal space, including the intrafamily relations. These processes of rearticulating of what meant to be "Orthodox", "Greek", and "Bulgarian" were expressed through symbolic and physical tensions. Attention to interethnic marriages was a symptom of deeper social transformations and political cleavages that were unfolding on multiple levels : the internationalization of the Eastern Question; the promulgation of the Tanzimat reforms with the concomitant reshuffling of Christian power brokers; the gradual and uneven integration into world economy ; the adoption of modern lifestyles ; and the conflation of patriarchal ideology with national aspirations. All these tensions eroded the Ottoman cosmopolitan culture in which auto-hellenization as a pragmatic desire of belonging to syncretic lifestyle was achieved through mixed marriages and grecophone practices. While such marriages offered economic prosperity they also came with social strings attached. Such behavior was acceptable until the 1830s but afterwards was stigmatized as "graecomania". Whereas interethnic marriages as social phenomenon gradually vanished from the urban tapestry, they captured the "convergencedivergence dialectic"91 of the cultural, socio-economic, and political life of the nineteenth-century Balkans: from auto-hellenization to de-hellenization, deottomanization and nationalization. When nationalism entered into the picture, the encounter between the traditional Orthodox culture with modern secular ideas reduced the communal spaces of negotiation, and shrank the in-betweenness of being " either a Gudila or a Bulgarian ». Hence, one of several entry points to modernity involved the subsuming of the flux of rich identities into a singular sense of national belonging and the "Graecomans" had to become (again!) Bulgarians.

\section{NOTES}

1. Bŭlgarski istoricheski arkhiv, Narodna Biblioteka "Sv. Kiril i Metodiı̌" [Bulgarian Historical Archive at the National Library "St. Cyril and Methodius"], hereafter BIA-NBKM, f. 49, a.e. 1, 6-7. N. Nikolaevich to h. N. Minchoglu, [1849]. All translations are by the author, unless otherwise indicated.

2. Kirkovich (Rada), Spomeni [Memoirs], Sofia : Pechatnitza “Kambana”, 1927, p. 22.

3. Tziovas (Dimitris), «Introduction », in Tziovas (Dimitris), ed., Greece and the Balkans : identities, perceptions and cultural encounters since the Enlightenment, Aldershot: Ashgate Publishing Limited, 2003, p. 7.

4. For a recent bibliography on the millet system, see Masters (Bruce), « Christians in a changing world ", in Faroqhi (Suraiya), ed., The Cambridge History of Turkey, vol. 3, The Later Ottoman Empire, 1603-1839, Cambridge : Cambridge University Press, 2006, pp. 272-279.

5. Todorov (Nikolai), Filiki eteria $i$ bŭlgarite [Philiki Etaireia and the Bulgarians], Sofia : Izdatelstvo na Bŭlgarskata academia na naukite, 1963, pp. 60, 85.

6. Stoianovich (Traian), « The Conquering Balkan Orthodox Merchant », The Journal of Economic History, 20 (2), June 1960, p. 290. 
7. As Popović has suggested : "Amongst the farmers in Srem every merchant is called Greek be it Serb, German, Jew ». Popović (Dušan J.), o Cincarima. Prilozi pitanju postanka našeg građanskog društva [On the Cincars. Contributions to the Issue of the Origins of Our Civil Society], 1927 (consulted ed.: Beograd : Prometej, 2000, p. 111) ; Stoianovich (Traian), art.cit., pp. 234-313 ; Livanios (Dimitris), «The Quest for Hellenism : Religion, Nationalism, and Collective Identities in Greece (1453-1913) », The Historical Review/La Revue Historique, 3, 2006, pp. 46-47.

8. Kitromilides (Paschalis), «"Imagined Communities" and the Origins of the National Question in the Balkans ", in Enlightenment, Nationalism, Orthodoxy. Studies in the culture and political thought of south-eastern Europe, Aldershot : Variorium, 1994, pp. 150, 160, 178, 192.

9. Hobsbawm (E.J.), The Age of Revolution 1789-1848, New York: Mentor Book, 1962, p. 174 ; Gounaris (Basil), «Constructing and Deconstructing a Common Balkan Past in NineteenthCentury Greece », in Detrez (Raymond), Plas (Pieter), eds., Developing Cultural Identity in the Balkans. Convergence vs. Divergence, Brussels : Peter Lang, 2005, p. 207.

10. Roudometof (Victor), «From Rum Millet to Greek Nation : Enlightenment, Secularization, and National Identity in Ottoman Balkan Society, 1453-1821 ", Journal of Modern Greek Studies, 16 (1), May 1998, pp. 11, 32-33 ; Livanios (Dimitris), art.cit., pp. 34, 40, 58 ; Petmezas (Socrates D.), "The formation of early Hellenic nationalism and the special symbolic and material interests of the new radical republican intelligentsia (ca. 1790-1830)», Historein, 1, 1999, p. 68.

11. Livanios (Dimitris), art.cit., p. 68 ; for a recent critique of the "bipolar historiographic schema" see Stamatopoulos (Dimitris), «Ecumenical Ideology in the Orthodox Millet $\left(19^{\text {th }}-20^{\text {th }}\right.$ c.) ", in Baruh (Lorans Tanatar), Kechriotis (Vangelis), eds., Economy and Society on both shores of the Aegean, Athens : Alpha Bank Historical Archives, 2010, pp. 204-210.

12. Danova (Nadia), «L'image du Grec dans la littérature bulgare (XVe-milieu du XIX siècle) », Études balkaniques, 2, 1994, pp. 20-23.

13. Danova (Nadia), « Obrazi na gŭrtsi i zapadnoevropeĭtsi v bŭlgarskata knizhnina prez XVIIIXIX vek » [Images of Greeks and West Europeans in the Bulgarian Literature during the $18^{\text {th }}-19^{\text {th }}$ century], in Aretov (Nikolaĭ), ed., Balkanski identichnosti v bŭlgarskata kultura, vol. 4, Sofia : Kralitza Mab, 2003, pp. 92-132, 93, 96 ; Danova (Nadia), «L'image du Grec » (art.cit.), p. 27.

14. Danova (Nadia), «L'image du Grec » (art.cit.), pp. 33-37.

15. Hroch (Miroslav), Social Preconditions of national revival in Europe, Cambridge : Cambridge University Press, 1985, pp. XI, 8, 23-26, 129.

16. On Fallmerayer see Herzfeld (Michael), Ours Once More. Folklore, Ideology, and the Making of Modern Greece, New York : Pella Publishing Company, Inc., 1986, pp. 75-81.

17. Inalcık (Halil), «Application of the Tanzimat and its Social Effects ", Archivum Ottomanicum, 5, 1973, pp. 100-101.

18. In his memoirs, Ivan Dobrovski mentioned that the so-called "Greeks" were mostly traders who lived in the central part of sliven and formed a sort of "aristocratic caste". Danova (Nadia),Ivan Dobrovski v Perspektivata na Bŭlgarskia XIX vek [Ivan Dobrovski within the context of the Bulgarian $19^{\text {th }}$ century], Sofia : Izdatelstvo "Valentin Traianov", 2008, pp. 46-47, 56.

19. Ivanova (Svetlana), « Status na gŭrtsite tŭrgovtsi v Rumelia prez XVII-XVIII vek», [Status of the Greek merchants in Rumelia during the 17th-18th century], in Konstantinova (Iura), ed., Balkanite, modernizatsia, identichnosti, idei. Sbornik $v$ chest na prof. Nadia Danova, Sofia : Institut za balkanistika s tsentŭr po trakologia, 2011, p. 68 .

20. Genchev (Nikolaŭ), Vŭzrozhdenskiat Plovdiv (Prinos v Bŭlgarskoto dukhovno Vŭzrazhdane) [Plovdiv during the National Revival. A Contribution to the Bulgarian Intellectual Revival], Plovdiv : Izdatelstvo "Khristo G. Danov", 1981, p. 37. This practice seems to be so prevalent that in an epistle from 1806 Patriarch Gregorius V banned the priests, deacons, and monks from becoming kumove (koumparoi). Snegarov (Ivan), «Gŭrtski kodeks na Plovdivskata mitropolia » [Greek Codex of the Plovdiv Bishopric], Sbornik na Bŭlgarskata Akademia na Naukite, XLI (2), 1946, pp. 257-259. 
21. For example, in the 1860 s when the town was politically divided, a very high percentage $(72,7$ percent) of those migrants sided with the Greek party. Lyberatos (Andreas), Oikonomia, Politike kai Ethnikē Ideologia. $\bar{E}$ diamorphosē tōn ethnikōn kommatōn stē Philippoupolè tou 19ou aiōna [Economy, Politics, and National Ideology. The Formation of National Parties in the Nineteenth-Century Philippoupolis], Ērakleio : Panepistēmiakes Ekdoseis Krētēs, 2009, pp. 53-57.

22. Victor Roudometof has suggested approaching this awareness of ethnic differences through the lenses of "ethnie," as articulated by Anthony Smith. Roudometof (Victor), art.cit., p. 12.

23. Lyberatos (Andreas), « From Stratum Culture to National Culture : Integration Processes and National Resignification in $19^{\text {th }}$ century Plovdiv ", Balkanologie, 8 (1-2), décembre 2011, URL: http://balkanologie.revues.org/index2274.html. Visited on February 20, 2012.

24. Tsoukalas claimed that in the old metropolitan codex there was not a single Bulgarian signature. Tsoukalas (Geōrgios), Istoriogeōgraphikē perigraphē tēs eparchias Philippoupoleōs [Historical and Geographic Description of the Philippoupolis Eparchy], Vienna, 1851, pp. 39-40. One of the few exceptions of such practices derives from a sale contract, which reveals that a certain Nikolau abacı together with his wife Ralou Matousē sold some property. He signed on his behalf and his wife's in Bulgarian, Church Slavonic script. Snegarov (Ivan), op.cit., pp. 274-275.

25. Tsoukalas (Geōrgios), op.cit., pp. 39-40, 44-45. See also Politis (Alexis), « Bŭlgarite prez pogleda na Gŭrtsite. Promeni v glednata tochka ot sredata na XIX vek » [Bulgarians through the Greek Eyes. Changes in their optics since the middle of the XIX c.], in Konstantinova (Iura), ed., Balkanite, modernizatsia, identichnosti, idei. Sbornik $v$ chest na prof. Nadia Danova, Sofia : Institut za balkanistika s tsentŭr po trakologia, 2011, pp. 343-344.

26. It is difficult to define its genre because it is a compilation of interviews, his recollections, anecdotes, and use of other sources. The manuscript was published after his death. Bernard Lory aptly calls it « une sorte de promenade minutieuse dans les rues de la ville ». Lory (Bernard), « Immigration et intégration sociale à Plovdiv au XIXe s. ", La Revue du Monde Musulman et de la Méditerranée, 66, 1992-1994, p. 95.

27. Lyberatos (Andreas), "To "Mnēmeio gia ton christianiko plēthysmo tēs Filippoupolēs" tou Konstantin Moravenoph : apopeira systēmatikou elegchou kai posotikopoiēsēs mias "poiotikēs" pēgēs» [The "Memorial of the Christian population in Philippoupolis" by Konstantin Moravenov. An attempt of systematic critique and quantification of a "gualitative" source], Ta istorika, 22 (43), 2007, pp. 336.

28. Moravenov (Konstantin), Pametnik za Plovdivskoto khristiansko naselenie v grada i za obshtite zavedenia po proiznosno predanie, ed.Victoria Tileva and Zdravka Boneva, Plovdiv : izdatelstvo "Khristo G. Danov", 1984, p. 17. Lyberatos also mentions the unknown fact that he was a Greek citizen, Lyberatos (Andreas), « To "Mnēmeio" » (art.cit.), p. 342.

29. Moravenov (Konstantin), op.cit., p. 15.

30. Detrez (Raymond), "Relations between Greeks and Bulgarians in the Pre-Nationalist Era: the Gudilas in Plovdiv », in Tziovas (Dimitris), ed., op.cit, p. 39.

31. See footnote 18.

32. Lyberatos (Andreas), « To "Mnēmeio" » (art.cit.), p. 361.

33. Moravenov (Konstantin), op.cit, p. 19.

34. Lory (Bernard), art.cit., pp. 96, 102-103 ; Lyberatos (Andreas), « To "Mnēmeio" » (art.cit.), p. 348.

35. Doxiadis (Evdoxios), The Shackles of Modernity. Women, Property, and the Transition from the Ottoman Empire to the Greek State (1750-1850), Cambridge / London : Department of the Classics, Harvard University, 2011, p. 76.

36. Clogg (Richard), ed., The Movement for Greek Independence 1770-1821. A Collection of Documents, London : The Macmillan Press, 1976., pp.91-92. 
37. Stoianovich (Traian), art.cit.; Tziovas (Dimitris), op.cit .; Tziovas (Dimitris), The Enlightenment as Social Criticism. Iosipos Moisiodax and Greek Culture in the Eighteenth Century, Princeton : Princeton University Press, 1992.

38. See, for example, the list of subscribers in Tsoukalas (Geōrgios), op.cit., n. p.

39. Madzharov (Mikhail), Spomeni [Memoirs], Sofia : Bŭlgarski pisatel, 1968, p. 184.

40. Moravenov (Konstantin), op.cit., p. 125.

41. Detrez (Raymond), "Kakva mania e grŭkomaniata?", [What mania is graecomania ?], in Konstantinova (Iura), ed., Balkanite, modernizatsia, identichnosti, idei. Sbornik $v$ chest na prof. Nadia Danova, Sofia : Institut za balkanistika s tsentŭr po trakologia, 2011, p. 360-363.

42. Danova (Nadia), « Kŭm istoriata na Tŭrnovskata gradska obshtina prez Vŭzrazhdaneto » [On the History of Tŭrnovo Municipality during the National Revival], Istoricheski pregled, 36 (1), 1980.

43. Snegarov (Ivan), op.cit., pp. 194, 204.

44. Tsonchev (Petŭr), Iz stopanskoto minalo na Gabrovo [From Gabrovo's Economic Past], Gabrovo : “Otvoreno Obshtestvo," 1996, p. 600.

45. BIA-NBKM, IIB 6441.

46. Biblioteca Academiei Romane, hereafter, BAR, Mss. sl. 738, 9-11. I am thankful to Ivan Biliarsky for pointing out this source to me.

47. BIA-NBKM, IIB 9910, pp. 29-30.

48. Boia (Lucian), Istoria i mit v rumŭnskoto sŭznannie [History and myth in Romanian identity], Sofia : Kritika i Khumanizŭm, 2010, p. 253.

49. Clogg (Richard), A Concise History of Greece, Cambridge : Cambridge University Press, 1992, p. 23.

50. Dertilis (Georges), « Entrepreneurs grecs: trois générations, 1770-1900 », in Angiolini (Franco), Roche (Daniel), eds., Cultures et formations négociantes dans l'Europe moderne, Paris: Editions de l'EHESS, 1995, p. 115.

51. BAR, Mss. sl. 738, 11-12. For similar examples see Todorova (Maria), « The Personal Accounts of the Bulgarian from the National Revival Period ", Etudes balkaniques, 3-4, 1992, p. 51 ; Lyberatos (Andreas), « Men of the sultan : the beğlik sheep tax collection system and the rise of a Bulgarian national bourgeoisie in nineteenth-century Plovdiv », Turkish Historical Review, 1, 2010, p. 63 ; Davidova (Evguenia), Balkan Transitions to Modernity and Nation-States through the Eyes of Three Generations of Merchants (1780s-1890s), Leiden / Boston : Brill, 2013, pp. 157-158.

52. BIA-NBKM, f. 169, a. e. 55, p. 1.

53. Karlova (M.), « Turetzkaya provintziya i eya sel'skaya i gorodskaya zhizn'. Puteshestvie po Makedonii i Albanii »[The Turkish Province and its Rural and Urban Life. Travels around Macedonia and Albania], Vestnik Evropy, 5 (3), 1870 ; Vestnik Evropy, 5 (4), 1870, p. 747 ; Davidova (Evguenia), « Gender and Culture in the Turkish Province : The Observations of a Russian Woman Traveler (1868) ", Aspasia. The International Yearbook of Central, Eastern, and Southeastern European Women's and Gender History, 6, 2012.

54. Kirkovich (Rada), op.cit., p. 28.

55. Lilova (Desislava), Vŭzrozhdenskite znachenia na natsionalnoto ime [The Meanings of the National Name during the National Revival], Sofia : Prosveta, 2003, p. 41.

56. Grigorovich (Victor I.), Doneseniya V. I. Grigorovicha ob' ego puteshestvii po Slaviyanskim zemliyam [V. I. Grigorovich's Reports about his Travels through the Slavic Lands], Kazan : Izdanie Otdeleniya russkago yazyka i slovesnosti Imperatorskoi Akademii Nauk, 1915, pp. 205-209.

57. Herzfeld (Michael), op.cit., pp. 124-125.

58. Macbridge (Peter), «A language in the image of the nation : Modern Greek and some parallel cases", in Beaton (Roderick), Ricks (David), eds., The Making of Modern Greece: Nationalism, Romanticism \& the Uses of the Past (1797-1896), Farnham : Ashgate, 2009, p. 177.

59. Mircheva (Keta), « Unishtozhavane na knigi - bŭlgarski praktiki i mitove ot XIX vek », [Book destruction - Bulgarian practices and myths from the $19^{\text {th }}$ century], in Konstantinova (Iura), ed., 
Balkanite, modernizatsia, identichnosti, idei. Sbornik $v$ chest na prof. Nadia Danova, Sofia : Institut za balkanistika s tsentŭr po trakologia, 2011.

60. Livanios (Dimitris), art.cit., p. 59.

61. Politis (Alexis), " La différenciation du comportement Grec vis-à-vis des Bulgares vers le milieu du XIXe siècle - problèmes de nationalismes ", The Historical Review/La Revue Historique, 6, 2007, pp. 107, 110, 117.

62. Minoglou (Ioanna), "Women and Family Capitalism in Greece, c. 1780s-1940 ", Business History Review, 81, Autumn 2007, p. 522 ; For Odessa merchants see Herlihy (Patricia), « Greek Merchants in Odessa in the Nineteenth Century », Harvard Ukranian Studies, III/IV, 1979-1980, p. 416.

63. Popović (Dušan J.), op.cit., p. 71.

64. Walker (Mary Adelaide), Through Macedonia to the Albanian Lakes, London : Chapman and Hall, 1864, pp. 257-258.

65. Vlamē (Despoina), « Gynaikes, oikogeneia, koinōnia tēs emporikēs diasporas 18os-19os ai. » [Women, Family, and Society among the Greek Commercial Diaspora in the $18^{\text {th }}$ and $19^{\text {th }}$ century], Ta istorika, 23 (45), December 2006, p. 258.

66. Todorova (Maria), Balkan Family Structure and the European Pattern. Demographic Developments in Ottoman Bulgaria, Washington : The American University Press, 1993, pp. 20-21, 45-46.

67. Stamatopoulos (Dimitrios), "The Christian Orthodox family in crisis: the Ecumenical Patriarchate's courts and the reconstruction of the private sphere in southeast Europe in the nineteenth and early twentieth centuries ", in Avdela (Efi), D'Cruze (Shani), Rowbotham (Judith), eds., Problems of Crime and Violence in Europe, 1780-2000. Essays in Criminal Justice, Lewiston / Queenston / Lampeter : The Edwin Mellen Press, 2010, p. 97.

68. Snegarov (Ivan), op.cit., p. 325.

69. Snegarov (Ivan), op.cit., pp. 369-370. Often Christian women preferred Muslim court in anticipation of a more favorable decision. On this issue see Laiou (Sophia), «Christian Women in an Ottoman World : Interpersonal and Family Cases Brought Before the Shari'a Courts During the Seventeenth and Eighteenth Centuries (Cases Involving the Greek Community) », in Buturović (Amila) and Cemil Schick (Irvin), Women in the Ottoman Balkans. Gender, Culture and History, London : I.B. Tauris, 2007.

70. BIA-NBKM, f. 628 , a.e. 1, p. 19, 24.

71. Drzhaven Arhiv na Republika Makedonija [State Archive of the Republic of Macedonia], hereafter DARM, Ohrid, f. 475, box 1, p. 1, 224.

72. Ēliou (Philippos), ed., Grammata apo to Amsterntam [Letters from Amsterdam], Athēna : Nea Ellēnikē Bibliothēkē, 1976, p. k $\varepsilon^{\prime}$. On diaspora's mixed marriages in Livorno see also Vlamē (Despoina), art.cit. pp. 265-267.

73. Clogg (Richard), The Movement for Greek Independence, p. 113.

74. BIA-NBKM, f. 49, a.e. 1, 6-7. N. Nikolaevich to h.N.Minchoglu, [1849].

75. Bakalaki (Alexandra), " Gender-Related Discourses and Representations of Cultural Specificity in Nineteenth-Century and Twentieth-Century Greece ", Journal of Modern Greek Studies, 12 (1), May 1994, p. 81.

76. Madzharov (Mikhail), « Na Bozhi Grob predi 60 godini » [Travels to the Holly Lands 60 years ago], in Giurova (Svetla), Danova (Nadia), eds., Kniga za bŭlgarskite hadzhii, $2^{\text {nd }}$ ed., Sofia : Akademichno izdatelstvo "Prof. Marin Drinov", 1995, p. 45.

77. Danova (Nadia), Ivan Dobrovski (op.cit.), p. 155 ;Philliou (Christine M.), Biography of an Empire. Governing Ottomans in an Age of Revolution. Berkeley : University of California Press, 2011 ; Voillery (Pierre), Aleksandŭr Ekzarkh. Edna bŭlgarska sŭdba [Alexander Ekzarkh. A Bulgarian destiny], Sofia : IK “Kolibri,", 2012, pp. 74-75, 264-265.

78. Cited in Lilova (Desislava), op.cit., p. 41. 
79. Radkova (Rumiana), Posmŭrtni materiali za bŭlgarski vŭzrozhdenski der̆tsi [Obituaries about Bulgarian Activists during the National Revival], Sofia : Akademichno izdatelstvo "Marin Drinov", 2003, p. 345.

80. Cited in Detrez (Raymond), «Relations between Greeks and Bulgarians » (art.cit.), p. 37.

81. On various distinctions see Naxidou (Eleonora), « The Routes to the Bulgarian National Movement. Simultaneously Homogenous and Polymorphous ", Sosyal Bilimler Dergisi, 2 (1), June 2012.

82. Boneva (Vera), Bŭlgarskoto tsŭrkovno-natsionalno dvizhenie 1856-1870, [The Bulgarian ecclesiastical and national movement 1856-1870], Sofia : Za bukvite, 2010, pp. 84-85.

83. Kirkovich (Rada), op.cit., p. 27.

84. For comments on assimilation see also Lilova (Desislava), op.cit., pp. 223, 254-255.

85. Danova (Nadia), ed., Arkhiv na Konstantin Georgiev Fotinov (op.cit.), pp. 407, 412, 446.

86. Kirkovich (Rada), op.cit., p. 22.

87. Makedonia II (14), 2 March 1868; BIA-NBKM, f. 6 IA8998, 258-259.

88. DARM, Ohrid, f. 475 , box 1, p. 73, 262, 426.

89. Davidova (Evguenia), « Kŭm istoriata na zaema za bŭlgarskata cherkva vŭv Fener -Tzarigrad » [On the History of the Loan for the Bulgarian Church in Phanar],Istoricheski pregled, 4, 1994-1995.

90. On the meandering fate of the Greek minority in the post-Ottoman period see Dragostinova (Theodora), Between Two Motherlands. Nationality and Emigration among the Greeks of Bulgaria, 1900-1949, Ithaca and London : Cornell University Press, 2011.

91. Detrez (Raymond),Plas (Pieter), eds., op.cit., p. 14.

\section{RÉSUMÉS}

This article employs Greek-Bulgarian interethnic marriage as a category of analysis to contextualize the intersection of language, class, gender, and nationalism. Such marriages reveal pragmatic practices of auto-hellenization as expressions of eclectic urban lifestyles that flourished in the Ottoman era up to the 1830s, a process interrupted by the emergence of nationstates and the Tanzimat that led to intra-millet conflicts in which the groups caught in-between became scapegoats. Also, Greek language (enriched with a Turkish and Slav mix), a blend that can be called Balkan commercial koinē, which played a cohesive role similar to its Hellenistic predecessor, became a target of linguistic nationalism. Thus, a natural demographic process was ideologized, entered national discourses, and eroded the Ottoman cosmopolitan life in which mixed marriages often united local versions of high and low cultures. Intermarriages captured the "convergence-divergence dialectic" of the nineteenth-century Balkan transitions -- from auto-hellenization to de-hellenization, de-ottomanization and nationalization.

\section{AUTEUR}

\section{EVGUENIA DAVIDOVA}

Portland State University, evguenia@pdx.edu 